\title{
What Comes to an End When a "Religion" Comes to an "End"? Reflections on a Historiographical Trope and Ancient Mediterranean History of Religion
}

\author{
Jörg Rüpke \\ Max Weber Centre for Advanced Cultural and Social Studies, \\ University of Erfurt, Germany \\ joerg.ruepke@uni-erfurt.de
}

\begin{abstract}
This article argues that the neglect of narratives about the end of religious traditions is due to a complex entanglement of our positions as historical narrators and specifics of the sources for histories of religions, that is of emic and academic narrators. Typically, academic histories are not only based on emic narratives, but also tend to accept their conceptual frameworks with regard to the unities of description. It will be shown that such an entanglement has consequences for the neglect of the end of religious practices or groups. Against this background an analytical grid for change and discontinuation of different dimensions of "religion" will be offered and exemplified in an analysis of the "end of Paganism" in the late ancient Roman Empire. The most problematic implications of such narratives, the article will argue, are assumptions about the coherence of the religious protagonists brought center-stage.
\end{abstract}

\section{Keywords}

religions - historiography - narrative - imperial collapse - dimensions of religion group formation - religious change

When did Christianity end? Was it with the Reformation, Luther, Calvin, Zwingli, and the end of the unity of the Church? Was it when rates of church membership fell below fifty percent in some important European cities? Or is Christianity still lingering on - or in a global rise? Answers might be easier when we concentrate on smaller areas. There are good arguments to suppose 
that we will witness the end of Christianity in Iraq, perhaps in Syria, either due to prolonged civil war or to new definitions of confessional monopolies. But is that what we mean in talking about the demise and end of a religion?

Probably, in each case the answer would be a clear "No." Without mass murder on the scale of genocide - I am thinking of the Cathars in Europe or the Aztecs outside of Europe - it seems to be difficult to state the "end of a religion." Even Paganism did not die after the destruction of, for example, major sanctuaries around the Baltic Sea; it survived in individual practices, has been revived even in its communal dimension, and is now acclaimed as a "world religion" (thus York 2003). These difficulties are neither trivial nor insurmountable. The thesis I am advancing in this article is a methodological, not a merely historical one. Claims about the end or continuity of a "religion" presuppose claims - typically not raised in the form of explicit presuppositions but taken as implicit knowledge - about the systemic character of such a "religion." Such statements about the systemicity are typically normative rather than descriptive. The very selection of criteria for continuity or discontinuity is decidedly interested, whether from the part of "organizational men," that is dissenters, or keepers of "heritage." Historians of religion need to disentangle these two sets of decisions. Such a task does not mean that they should aim at value-free judgments. This is simply impossible. Instead, I propose to reflect on one's own criteria and their implications, as typically very particular decisions by religious (or historical) actors are simply reproduced by academics. This is due to a complex entanglement of our positions as historical narrators and specifics of the sources for histories of religions. This entanglement can be demonstrated for several narratives and has consequences for the neglect of the end of religious practices or groups. Against that background, I will reflect on the task of narrating the demise of religion and the constitution of the subject of such narratives and propose a new analytical grid. Accordingly, I will analyze the "end of Paganism" in the late ancient Roman Empire as a case study, leading to a brief conclusion.

\section{The Problem of the End}

Religious studies are fascinated with origins. Origins cater for an academic interest in the surprising, in the unexpected elements in history, which triggers closer analysis and mobilizes intellectual labor (Smith 2001: 145). Founders and founding events are favorites among the topoi of academic accounts of religion, from "world religions" to "new religions," from the "entering of Buddhism into China" to the "ancestors" of Japanese New Religions (e.g., Campany 2017; 
Reader 2006, 2009). Narratives have to start somewhere and the biographical narrative or the organicist metaphor of the birth of an institution modeled on biographical narrative offer an easy solution to the problem of narrative framing. Here, a, if not, the most important, decision has already been made, namely, the choice of the subject. It is an individual or (more usually) collective agent. Quasi-organic systemicity is presupposed. To give an example of such reasoning and narration: Ceteris - and this is important - paribus a small addition in beliefs entertained and the infrequent participation in a further network turned "Jews" (e.g., Latin-speaking inhabitants of Ostia with Roman citizenship) into "Christians" in some contemporary texts and in the overwhelming majority of academic accounts of the first centuries CE.

Yet, such an option for a biographical metaphor is the more important, as framing is an important factor of imbuing meaning to a story (Koschorke 2012: 62-63). For instance, the problem of a lack of motivation for the sequencing of events is solved, as biography easily allows motivation to take the form of attributing agency, either to human or to collective actors, thus producing "over-coherence" of the not any longer contingent course of events. Evidently, for such a form even of academic narrative, emic narratives offer themselves, following an interest of establishing not only traditions, but also their legitimacy. The critical academic appraisal of such emic narratives focuses on stripping (for example) the attribution of superhuman agency. Otherwise selflegitimizing emic narratives of "origins" are welcome.

Stories likewise need endings and not necessarily happy endings. This is easy to accomplish with regards to individuals and their biographies. Emic and academic "Lives" would hardly do without the end, whether peaceful or violent. It is sealing the life's value or its "true character" and - highly relevant as a motivation for the narrators - authenticating the message or beliefs shared (Waldner 2008). Some sort of deification on the basis of martyrdom, disappearance or an incorruptible corpse or at least ongoing reception are typical results, in emic or academic terms. With regard to the history of a collective agent, a "religion" in whatever institutional form, this does not apply. Usually it is the ongoing existence or effect of such a subject that triggers the whole business of emic and academic narrative as giving answers to questions of explanation, evaluation, or orientation (see Rüsen 1996). Certainly "end" is a dramatizing element and hence a nice title catchword, but in the actual narrative it is interpreted as a (mere) crisis: something is coming to an end, but above all the underlying subject is just experiencing a form of transformation. The "end of the Roman republic" marked by the death of Julius Caesar and a change to a veiled form of monarchy is an example for that and easily banalized 
as just one instance of ends of several republics, each marked by major constitutional changes that changed the sense of "commonwealth" (Flower 2010). In other instances, the end just signals the next step in a sequence of natural or evolutionary "progress"; such an end is "final," but without interest in what has ended, whether one of the first three empires in the biblical scheme of four or the present age in apocalyptic imaginations (in general, Nagel, Schipper, and Weymann 2008).

More substantial interest for the "dead" subject is being catered for by "antiquarian interest," notoriously lacking notions of temporal change (Maas 1992; Miller 20o1; Alroth and Scheffer 20o9; Mulsow 2014). Lacking, too, is an interest in the systemicity of the subject investigated. Mechanically ordered lists and representations, whether in written or museal form, are consequences. As this is not a fitting basis for an account interested in historical change as posited here, a problem of sources accrues. If the end is not dramatic, it is difficult to grasp. It is much more plausible to take a first attestation as a beginning, an innovation, as to take a last attestation as an end. Words, practices, objects often stay in use for long before they not dramatically fall into disuse. Even a horizon of destruction might be compensated by a rebuilding in another spot. It is not only the discipline of the History of Religion that has been less interested in ends than in origins and essences. Anthropology or archaeology easily join the list (Woolf 2017: 115). Yet, I would like to stress that for historians of religion it is particularly unusual to speak of the demise of religion as such narratives could hardly be built on our usual sources, that is above all emic accounts, which happen not to share this interest (with only few exceptions to which I will come back). Memories manifested in religious media are rarely memories of ends.

As a result of the efforts undertaken by religious agents to interpret and identify themselves through their past, scholars of the history of religions have a large body of sources that is imbued by narratives, which were produced to serve the very purpose of creating clearly defined "traditions" or "communities." We also have claims that shared bases and dividing lines found in these sources are the results of such narratives or embody the strategic interest that triggered the narratives in the first place. I have discussed this collaboration of historians and religion and their sources at length elsewhere (Rüpke 2011a, 2015a). Such narratives are produced with much ingenuity and energy and offer accounts with great plausibility. Historians of religion, supposed to produce 
"etic" accounts, but at the same time striving to understand their scholarly objects by interpretation (see Smith 2001: 143), tend to follow the constructs produced by historiographic sources and to ignore the subjective and interpretive nature of their framework. Memorized detail and postulated framework reinforce each other - a massive problem for further conceptualization in any re-narration, as we will see. Identities and interpretations generated by religious communities in the course of historicizing themselves are taken over by scholars as if they may legitimately be used as valid models on the basis of which to study the history of religion. As a consequence, the very "religions," about which we predicate "demises" and "ends," are not least historiographical inventions - emic and academic (Rüpke 2018a).

The resulting entanglement of emic elaborations and academic reception have been illustrated in a number of recent studies. I will restrict myself to a few examples with a focus on the ends that are implied in these narratives. The history of the Exodus story, a supposedly genealogically constituted group fleeing from their social and spatial context in Egypt and thus constituting a "people," became a cornerstone in the Rabbinic imagination of the past from the $3^{\text {rd }}$ and 4 th centuries onwards. Many different voices work on the unification of a history, the snippets of which were to be found in the biblical tradition. Midrashic interpretations outlined the biblical tradition to create an overarching historical context reaching back to the patriarchal period and even earlier and forward up to the actual present. Its focus and hermeneutical key is given by the Exodus story, which became inscribed into ritual texts and thus allowed for the appropriation as a foundation of a specifically Jewish identity far into the historiography of Judaism (Stemberger 2018). Such a recreation of the past on the basis of biblical texts did not, however, begin with Rabbinic interpretations. It can be observed earlier in the creation of Moses as the founding figure of Israelite and Jewish religion in his multiple roles as the leader of the people of Israel, lawgiver, and true prophet. From Antiquity onwards down into present scholarship the discourses of a political leader and of Judaism as the religion of the law were intertwined. The topos of the lawgiver has been as attractive to historiography as to past and present cultural theories and exegetics (Kratz 2018). Evidently, it was not the end of the form of Judaism practiced in Egypt, that was the center of interest, but the beginnings as construed in the culturally void space of the Sinaitic desert. The end is the end of the Egyptian army only, narrated in a few lines and celebrated in an old song. Ritual practices, Passover, too, if we employ the analytic grid just developed, focus on the exodus as a constitutive beginning, not on any more detailed representation of the status quo ante. 
As Christian stories will come into play later, in my quick chronological review of narrative formations, I jump to the explosion of fictive narrative detail already in the earliest phases of written accounts on Muhammad's life. Quickly, many and competing narrative accounts sprang up. Political functions, in particular the legitimation of an Umayyad dynasty under attack, were one part of the story; but first and foremost, the narrators themselves were in need of authority, which was provided by the plausibility of their narratives as well as by their professional access to details and soon to chronology also. The past was malleable, but to a limited extent only. Established images of prophets constrained the new and greater prophet (Robinson 2015). The end implied here, is the end of pre-Islamic Arabic polytheism, of idolatry. Reduced to a few graphic scenes, it is the end of something different, the end of the "others." Such an end is not of further narrative interest and renders any academic account extremely difficult.

To add a European example, French Protestant historiography of the late 16th and 17th centuries was a sort of text answering the question: Where was your church before the Reformation, before Luther and Calvin? The heuristic apparatus developed included dogmatic inventions and critique before 1500 , individuals who spread new ideas, and the continuity of groups from Apostolic times onwards who served as "witnesses of the truth" against the majority of the papal Church. Narratives of martyrdom were important for the historiography of groups that remained defeated minorities in their struggle with French Catholicism (Krumenacker 2015). Here, ends of individuals and even temporary ends of local groups were given importance to stress overall and continuing endurance - a way to deal with ends that was popular from the Hellenistic stories of martyrs in the books of the Maccabees onwards (Van Henten and Dehandschutter 1989; Leemans 2010; Maier 2016).

A last example illustrates a very different mode of ending, namely by silencing. In 17 th-century Mongolia a rich variety of what I would call denominational historiography existed. These many voices gradually disappeared in the development of a dominant view on the history of Mongolian Buddhism that had been only one among many older narratives before. Modern scholarship collaborated with its "sources" in replicating some claims of exclusiveness. In the end, Mongolian Buddhism is equated with Gelugpa Buddhism, and Mongolian history of religion was written as the latter's history (Kollmar-Paulenz 2018). The ends of other varieties of Buddhism are no factual endings but are the loss of agency and presence in historiography as seen by meta-historiography. This is far from dramatic and is neither attributed to divine agency nor celebrated in rituals. 

Grasping Ends

The preceding review allows for an initial conclusion. The lack of academic narratives about demise and end is the consequence of a lack of a discursive formation, a field of voices that does not just indulge in others' ends but needs to and can be argued against. Religious narratives that typically form such discourses make claims about the agency of their god or gods, embed the period of demise within a larger temporal horizon, deal with the end in rituals or images, and intensify production within contexts of - sometimes violent competition (see Otto, Rau, and Rüpke 2015: 4-6). Evidently, all of this presupposes the ongoing existence of the religious collective (whether an existing group or imagined community), the end of which forms the subject of the narratives. Yet typically, the factual end as narrated is improbable. As we have seen, the factual end or effective silencing leads to rather laconic statements in emic narratives. As narrated from outside, their interest in details of decline and demise before any dramatic end (which certainly invites narration) tends to be restricted, mainly kept alive by ongoing controversy or enmity. Academic interests might develop later, but, as this thematic issue demonstrates, in very different contexts, on systematic reasons - the witnessing of the extinction of languages, contemporary instances of genocide - and not as an organic part of the historiography of some religious tradition. And that is to say, often much later.

If an academic historiography of demises and ends does not grow organically out of narrative controversies on the ground, the definition of the very subject of the new account - in the other instances a result of sometimes brutal interests of exclusion or inclusion, legitimation and de-legitimation, of appropriating or ceding genealogical positions - is not any longer given. Gelugpa Buddhism, Valdensians, Rabbinic Judaism, or "Islam," or "Sunna” built on Muhammad as a new prophet, that is, the examples presented before, were not some "natural" units, but were highly profiled positions, the results of complex processes of grouping and discursive boundary-making, in a dense field of competitors.

As a consequence, we need to answer the question: What degree of generalization is aimed at by our interest in the demise of religions? Recurring on Jonathan Z. Smith, it needs to be pointed out that even generalizations do not aim at the universal but at inquiring about the reach and limits of constructions based on fragments and particulars (Smith 2001: 140-141). Evidently, "world religions" are hardly an adequate unit of description, even if we continue to hear and read about "the victory of Buddhism" (see Bowring 
2008 for Japan; Campany 2017 for Chinese sources), or the "Hellenization of Christianity" and even about Christianity, Judaism, and Paganism (in the late antique Mediterranean context, for example), as if these were all separate, stable, and unified entities which may or may not have influenced and interacted with each other in various ways. Such terms and conceptualizations are put forward by religious historiographic agents (most famously Eusebius; see Vinzent 2019). This is as problematic for beginnings and ends as for comparable generalizations about religious change in between. The concept of the "Hellenization of Christianity" is an extrapolation from false dichotomies and portrayals of the appearance of Christianity on the world stage as a separate and new entity and is proffered by Christian historiographers. How should we imagine that and forge the corresponding terms for talking about ends? In the absence of a fundamental revision of our approach, piecemeal criticism is cheap, but volatile. Franz Cumont elaborated the idea that Christianity made its inroad into Greco-Roman polytheism on the back of other Eastern mystery cults, the so-called Oriental Religions (Cumont and Bonnet [1929] 2006; see Lannoy 2012). Today, we criticize Cumont for his classificatory strategy and his diagnosis of a paganism dying for lack of morality, for lack of perspectives of individual salvation and universality (see Praet 2014: 292), that is to say, for Cumont's diagnosis of the demise and end of a religion. Contemporaries in the early 20 th century castigated him much more for providing a pagan prehistory to Christianity (Praet 2014: 296; see Lannoy and Bonnet 2018; Lannoy 2020).

The example of Cumont suggests that academic narrative - which should not hide behind emic hypergeneralizations in the case of beginnings and cannot hide behind emic hypergeneralizations in the case of ends - should be self-critical in two respects. First, it needs to be critical about certain tropes that offer themselves, for instance, in applying models from biography to our objects. Are we interested in famous last words like biographical narratives or in the death of the last believer? Is the tendency to operate on the basis of humans' agency or metaphorical variants inherent in narrative the best approach for dealing with the undeniable facts of demise of religions after we have just witnessed the demise of the narrative of the demise of religion in the singular, that is, secularization narratives and their theorizing (on new alternatives in Beyer 2013; and Burchardt and Wohlrab-Sahr 2013)? This question leads to the second respect and the main claim of this article. For which purpose do we need to concatenate so many religious data, about which we could make meaningful statements of change - the aforementioned fragments and particulars like media, practices, beliefs, roles, and specialists? Why do we need to theorize them as "religions," only to revisit them as indicators of a generalized "demise" or "end" of these constructions? Evidently, even at first glance 
many of these phenomena fall outside the borderlines of "religions" and "religious groups," which tend to offer themselves as natural objects of narratives of demise. Concepts like "folk religion," "popular religion," or "shared religious practices" and koiné refer to a wide field of religion beyond specific collective identities (see Rüpke 2018b for Late Antiquity).

This leaves two alternatives for academically meaningful talk about ends. In the first scenario, we theorize "religions" as encompassing generalizations of as many phenomena as possible and invest in claims about their systemic interdependency. As a consequence, identifying these "religions"' ends is meaningful and consequential. However, in order to be able to do so, we must be able to defend all the presuppositions made before, which I presume to be frequently built on normative claims by interested religious actors. In the second scenario, the concept of "religions" is reduced to a small and easily intersubjectively testable number of highly interdependent phenomena. On these, statements of demise and ends can more easily be made. However, even plausible results would not be highly meaningful and consequential, as they do not go beyond the small range of phenomena taken into account in the first place. If I reduce "Christianity" to some "visible" Church, the latter's end would undeniably indicate the end of the former. Such an insight would, however, hardly be of added value.

This reasoning leads to a radical proposal. Following the widespread critique of the concept of religions and its comparative applicability, I suggest not to start from the complex clusters called "religions," but to focus on lived (historical) religion (Albrecht et al. 2018; Rüpke 2019; Gasparini et al. 2020) and religious agency (Rüpke 2015b, 2018d). With a view to analyses of demise I propose to bracket the notion of "end" and to talk about processes of religious change in the four dimensions of practices, beliefs, group formation and institutionalization (the latter two I suggest to separate), as particularly internal dynamics and the external (or internal) escalations of destruction of objects and persons.

Hence, the resulting analytical grid proposed here encompasses:

(1) reduction in frequency, in participation rates and discontinuing of ritual practices,

(2) weakening, metaphorization or dropping of beliefs,

(3) disassociation of group formation from certain practices or beliefs in both directions (believing without belonging and belonging without believing resp. practices),

(4) de-professionalization of religious specialists, weakening of religious organization or even dissolution of groups, 
(5) negative social sanctions (sometimes taking the form of legal norms) of practices, beliefs, grouping, and institutionalization,

(6) the destruction (removal, breaking to pieces, or burning) of religious sites, symbols, or textual media,

(7) and only in some extreme cases also of selective killing or even genocide of the very agents of the practices, beliefs, or institutions under consideration.

Whether the one or the other amounts to the end of some "religion" in the balance of continuities and discontinuities (on the problem see Stausberg 2001) is a matter of definition a priori, not a posteriori, running into the risks of thoughtless normative claims or overstated conceptual claims of irrelevancy. In any case, as I have shown, the framing of the story needs normative legitimation, the actual narrative empirical evidence.

The course of my argument needs at least one empirical case to put the suggestions to the test. My case is taken from one of the hot spots of historical change in matters religious, the late ancient circum-Mediterranean empires, seen as the formative phase of Christianity and Judaism (Boyarin 2004, 2008). It was a world in which a singularizing perspective on religious practices, beliefs, and identities came to the fore, conceptually excluding the possibility of practicing or adhering to more than one of the "religions" (Rüpke 2016b). Thus, retrospectively, the earlier dominating "religion," called "Paganism," must have come to an end.

What do we mean by speaking of the end of Paganism in Late Antiquity? Peter Brown, in a masterly synthesis of the tidal change in studies on Late Antiquity during the last half century, noted as one of the few certainties: by the end of the fourth century Paganism was dead (Brown and Lizzi Testa 2011). Animal sacrifices and public priesthoods, public financing, and the games had come to an end. ${ }^{1}$ In a detailed study for Asia Minor, including sources typically overlooked, Jan Bremmer comes to the same conclusion: there is no "indication that a coherent pagan religious system was still surviving in the Anatolian countryside," just "fragments" (Bremmer 2017a: 47). The same author, however, has stated at the very beginning of his chapter that Paganism was not a single

1 The basic narrative has changed only slightly, see: Beugnot 1835; Boissier 1891; Chuvin 1990; Curran 200o; Cameron 2011; Lizzi Testa 2013; Watts 2015. 
block (Bremmer 2017a: 33n1, referring to Glen Bowersock). So, what was really dead, if we read that pope Gelasius wrote on the contemporary attractiveness of the festive practices of the Lupercalia nearly two centuries postmortem (Holleman 1976)? Was it, to move beyond the period addressed by Brown or Bremmer, if we read 6th-century Caesarius of Arles on rural Gaul, 11th-century Adam of Bremen on Scandinavia, and 12th-century reports on the Prussians (see, e.g., Bailey 2016: 72-73)? And what about neo-Paganism, Celtic revivals, and 21st-century Greeks venerating Zeus and Aphrodite statues positioned next to their TV set (e.g., York 2003; Stausberg 2009; Stroumsa 2013)?

When do major innovation or discontinuities signal the end rather than the vitality of a set of religious practices, beliefs, group, or organization? Given the complexity or multidimensionality of religion, trajectories of continuity and changes might be very different. Practices and concepts, organizational features, and some social or ethnic group at the center of such practices and beliefs might fare very differently, not least depending on the external pressure on these phenomena. The grid just developed might help structure a quick review.

With regard to widespread and traditional practices, animal sacrifice was much debated throughout Antiquity (Ullucci 2012), but even massive philosophical opposition in the 4th century did not hinder the continued nexus of slaughtering and feasting, constitutive for a lot of earlier festivals (see Bremmer 2018: 228-231). The term, however, became important in different contexts, referring to human bodies, martyrs on the one hand, ritualizing a vegetal meal, the Eucharist, on the other (Rouwhorst 2017: 144). The metaphor of sacrifice as applied to the death of Jesus and the Eucharist became a dividing line as late as the 16th-century Reformation and as applied to death in war an instrument to link national and religious agendas in the 2oth century (for the latter, see Seeber 1991). Other practices, perhaps even more widespread, changed even less. The concept and ritualization of vows hardly varied but in the change of addressees, from deities to martyrs and saints for instance. Surely, there were transformations. Widespread urban literacy had produced lasting textual evidence in the form of dedicatory inscriptions, which declined in the de-urbanized Western parts of the Roman Empire; body votives had their ups and downs (for instance in the last century BCE). Overall, the materiality of religious practices continued with the variation of nuances only (e.g., Hunter-Crawley 2012; Denzey Lewis 2017; in general, Morgan 2015). This holds true from amulets worn on the body (e.g., Gordon 2011; see also Choat and Gardner 2013) to the continuing role of altars and the textiles, paintings, and mosaics of sanctuaries (cf. Moormann 2011; Frankfurter 2008). Pilgrimages 
continued to be a hallmark of the large space of religious action opened by the empire, even if shifts of location - from Eleusis to Jerusalem - are undeniable (Elsner and Rutherford 2005; Luginbühl 2015; Bremmer 2017b; Handley 2017). As already indicated, many festivals continued, stripped of the most explicit forms of veneration of gods different from the biblical God, Jesus, and saints (in general, Dasen and Schädler 2013).

To turn to beliefs, the divinization of humans, most prominently, but not exclusively (if we think of ancestors addressed as Di manes) of emperors and Jesus, had very different fates: emperors were "gods" (divi) deep into the $5^{\text {th }}$ century (Boin 2015: 156), and the "sacredness" of the ruler remained an important, even if debated, figure of speech far into post-ancient political and theological debates. The transmigration of the soul, a rising concept of the imperial period (Albrile 2015), a criterion for defining heretics for centuries, has become a mainstream position in contemporary Europe, widely shared among members of Christian Churches (see, e.g., Zander 1999; Fischer 2013). Slowly, the body of narratives used and retold changed - as it had done during the preceding millennia. Biblical narratives accrued in general use (Rüpke 2005), but figures like Hermes (Trismegistos), Dionysos, or the Sibyls were continuously present in narratives far into Late Antiquity and beyond (Ebeling 2007; Shorrock 2011; Momigliano 1992; Lightfoot 2007). Without doubt, the locus of knowledge production shifted, at least (and again) in the West, from cities and urban elites and academies to monasteries as distantly located as Ireland, and only later back to urban universities. With regard to notions of divinity, (not only) in the East the identity of cultic functionaries and theoreticians in the figure of the bishop shifted the divide between monotheistic theorizing and polytheistic ritual practice from public to more individualized ritual performances, declared irrelevant by concepts of "popular religion" or "paganism." I will come back to this notion at the end.

Group formation as a dimension of "religion" developed only slowly over the course of ancient Mediterranean history (Rüpke 2018c). It is for Late Antiquity only that we find evidence for developed concepts of membership, across diverse sets of practices and beliefs, that is to say, also beyond Judaeo-Christian groups. It is such groups and related specialists that we see thematized in legal norms as collected in the Theodosian Code of the 5 th century CE. The notion of co-extension of group membership and beliefs held - as given pride of place in Augustine's De vera religione - increasingly became an instrument of marking boundaries. This general process was marked by uneven gains in the degrees of overlap and explicitness rather than losses of certain "religions." The prolonged conflict about Sunday adherence, the fulfillment of a norm of obligatory 
participation for group members in Sunday services, can be witnessed through Late Antiquity down to the ages of confessionalization, Counter-Reformation, and the French Calendar revolution (Rordorf 1972; Meinzer 1992).

Organization: Even if public priesthoods like pontifices and sacerdotes had been discontinued in the 5 th century (and never had the coherence of Christian clergy, Bremmer 2017a: 48; end: Rüpke 2008, 2011b), the very terms and many of its associations became a hallmark of medieval Christian Churches (Ronning 2007; Kajanto 1981). The high visibility of members of urban elites in religious roles shifted from the old institutions, cofinanced from public funding far into the second half of the 4th century, to other offices, political, but also ecclesiastical, to bishop or notary (Heinzelmann 1976). Small religious entrepreneurs continued to offer their services in the fields of healing and divination.

Rural and urban topography (Goddard 2006; Leone 2013; Blömer and Eckhardt 2018), myths and rituals (cf. Cecconi 2007; Machado 2009; Shorrock 2011; Kristensen 2012), meals and funerals (cf. Belayche 2007; with Petts 2011: 38), religious specialists and administrators (e.g., Ferri 2016; Teitler 2016) could develop very differently. The same holds true for social sanctioning in its various informal or institutional forms. To start with the last point of the grid, the use of violence was restricted to rare events and specific local constellation (Shaw 2011), repeatedly at Alexandria for example (Haas 1997; Isele 2010; Watts 2010; Arcari 2017). Legal restrictions were formulated for very few practices and (as much of Roman legal norms) formulated for particular regions. Draconian punishments clashed with evident problems of proof. Frequent repetition of comparable norms decried their effectiveness (Noethlichs 1971, 1986, 2015). And yet the ultimate proof was always a local, imagined or real, event, the destruction, dis-use or re-use of a former "sacred place" (e.g., Hahn 2008), whatever the real consequences in terms of continuity of cult or belief were (see Cohn 2013; Belayche 2018: 231-232; similar for China: Campany 2017: 20, 33). Here archeological evidence is difficult to assess - as I have pointed at before, it is much easier for archeology to achieve valid results for origins than for ends (Sauer 2002). Many monumental buildings were treated as hallmarks of urban pride and importance, proudly protected from any harm.

How could we summarize such findings? As seen from the developments of the late Roman Empire, religion appears as a toolbox rather than a language. Religious agency was widely and unevenly distributed. Group formation and organization, shared practices and shared beliefs are aspects that are neither necessarily nor uniformly interlinked. The death of the last practitioner of some ritual or last believer of some idea - to press the comparison with language development - does not equal the death of "a religion." If necessary, some material item might stand in for the demise or rather destructibility of some 
forms within the dimensions of religious practices, beliefs, social and institutional forms. Images of the gods might be rendered useless by just smashing their noses, thus allowing Jews the ending of pagan idolatry, as stated in the Mishnaic tractate Avodah Zarah. Texts, "scripture," might be re-ascribed and appropriated, thus rendering a Christian group verus Israel, "true Israel" (see Boin 2014: 189) or the 1st-century BCE poet Vergil a Christian ante litteram and a religious authority anew. At the same time, the argument that religious conviction can be hidden and practices only interrupted or moved to secrecy can suggest that the killing of people is the best way to end a religion. This path was hardly ever trodden in the Mediterranean empires of the 4th-6th centuries after the violent attempts to end religious strife in the second half of the 3rd century CE.

\section{5}

\section{Conclusion}

There is no doubt that cultural institutions (in the wide sociological meaning of the term) can weaken and even end - whether forcefully or not. However, the very process of defining the extent, defining elements, coherence, and liveliness of conglomerates of practices, beliefs, and organizational features is a strategic move, made by interested parties long before scholars of religion (Stausberg 2001). Claims about (frequently one's own) continuity and others' discontinuities are strategic instruments of institutional claim-makers and functionaries. Thus, third-order descriptions have to be aware of such claims and to reflect upon the relationship of one's own narratives to such normative claims. The observations made above about changes in Late Antiquity, here taken as the period between the 3 rd and the sixth century, can hardly be brought together in a single narrative. With regard to the problem of the definition of the subject, about which statements of decline and demise are made, one has to state that "religions" are not simply given or self-evident as the subjects of birth and death, growth and decline, flourishing and demise. The very drawing of the relevant boundaries is an important aspect not only of the historical narratives that form part of the basis and competitors of scholarly accounts.

Stefan Alkier and Hartmut Leppin have recently suggested to talk about "Christianity" and "Israelites" (comprising, e.g., Jews and Samaritans) as "umbrella terms" only; "Paganism" is not deemed helpful and might be replaced by "polis and rural cults" (Alkier and Leppin 2018: 441-442). However, we have to take even one step further. Revisiting claims about the relationship of "Paganism" and "Christianity" in the light of postcolonial studies has 
demonstrated how far distortions of such terms and narratives can go (see Petts 2011: 31-33). The most urgent problem is not the distortion of local variants by comprehensive abstracts, but the ordering effect on the whole field of data, the framework drawn by all these terms. The final problem is that the emergence of religions itself is a historical process that is the decisive part of the events captured in the standard narratives, the end not of "Paganism" as opposed to other contemporaries, but of a religious field that is not structured by the existence of "religions."

Religious interaction in the Ancient Near East has been intensively studied since the end of the 19th century by the Religionsgeschichtliche Schule but has remained focused on developments leading to or interacting with what is called "early Christianity." More recent studies have, however, demonstrated that imperial society could identify religious practices or groups of adherents to religious figures ("Christiani"), but neither provided the necessity nor opportunity for an exclusive and totalitarizing religious self-identification (Rives 2011: 278-80; Rüpke 2012, 2018c). "Judaism" and "Christianity" as incrementally coherent blocks are themselves a late product of processes of complex and gradual mutual differentiation rather than an easy "parting of the ways" of a pair of independent actors (Boyarin 2004; Burrus et al. 2006; Dunning 2009). Even intellectual religion could exist with and without a basis in local groups (Gnosticism, Hermetism; see Rüpke 2016a). These processes were part of momentous political changes, the establishment of an empire and the concomitant "mediatization" of hundreds or even thousands of smaller, local political units, and of the breakdown or at least massive shrinking of this empire.

If the development of the empire shifted the balance of the local to the "universal," this affected all religious practices and groups. One might talk of the end of local religion here. At the same time, urbanization deeply changed the character of the "local," rendering local religion into a multifocal, polyphonic, and intellectualized practice (Rüpke 2020). "Religions" formed accordingly, identifiable only in their most intellectualized or institutionalized forms, Neoplatonism, many different Christianities, Greek and Rabbinic (and certainly also Latin) Judaisms. Their "universality" reached as far as the Empire, that is, just around the pond of the mare nostrum. In their bookish forms they were not to die anymore.

And yet, the process of the conceptual formation of religions was a slow process. "Paganism" as a religion was yet to come. Eusebius of Caesarea wrote an "Ecclesiastical History" (Hist. eccl. 1.1.1), even if modern translators render his ekklesiastikê in later passages frequently with "Christian" (e.g., Lake 1926: 1.1.5 with 10n1). For contemporaries, idolatry was a practice, polytheism an intellectual aberrance. For centuries to come, Paganism was a problem not least inside the Church (and growingly Churches). For Protestants, it was comparable to 
papism - and actually frequently combined (e.g., Ormerod 16o6). "Paganism" (as well as paganisme or Heidentum) was a period like Antiquity, surely with its own forms of religious practices and beliefs far into the eighteenth century (Anonymous 1722, 1750; DuLignon 1753; Burigny 1754; Bergier 1767; Sainte-Croix and Lenz 179o). Only very slowly the ideas of "syncretism," of the concretion of practices, beliefs, and institutions, produced Paganism along other religions (e.g., Johannes and Hagen 1796). On the back of Gibbon's Decline and Fall of the Roman Empire (1776) Heinrich Gottlob Tzschirner wrote a Fall of Paganism (1829). In 1830, the Académie royale des inscriptions et belles lettres published a Preisaufgabe, a call for works on that topic. The line of works still quoted and reprinted today followed, starting with the winner, Auguste Arthur Beugnot (1797-1865), who published his History of the Destruction of Paganism in the West in 1835 (Beugnot 1835). Paganism was a religion. Yet, it is noticeable how careful the French Academy had formulated the task, as can be read in Beugnot's preface (ii): it demanded to fix the time when the namely invocation of gods from Greek or Rome was stopped. In his reaction, Beugnot himself freely used ancient cult and ancient religion as synonyms. But if Paganism was a religion for him, he was also aware of its nonending. Thus, he entered into a discussion about its systemic character at the end of his preface (viii): he takes Charlemagne as a pragmatic end to his study (crowned 8oo CE!), whom he considered as the conventional boundary between "ancient and modern society." Doubtless, he admits, as a "tradition" Paganism continued beyond and until his own days, even if not - and this is decisive for him - as a "partie intégrante du culte romain." Nearly two hundred years ago, the concept of "religions" was not as natural as today (see, e.g., Friedheim 2006).

As I have argued in this article, the paramount problem of a historical analysis is not posed by identifying and describing demises and ends. Generations of historians have taught us to ever improve our parameters for their analysis and I tried to contribute to an improvement of our analytical grid and terminology to capture more precisely the discontinuities and violent breaks. The paramount problem is formed by the very subjects of which we predicate such developments and states and by the contexts we admit and take into account. Here, terms built by generations of historians have to be revised. Maybe, we have to consider whether talking of "religions" is coming to an end.

\section{Acknowledgments}

This article was drafted during my stay at the Centre for Advanced Study, Oslo, in the framework of the project "The Demise of Religions," directed by Michael Stausberg and James R. Lewis. I am grateful to all members of the group for 
reading and discussing this text and Markus Vinzent, Erfurt/London for further comments. I am also grateful to the staff of the Centre for its hospitality and effective as well as friendly support.

\section{References}

Albrecht, J., C. Degelmann, V. Gasparini, R. Gordon, M. Patzelt, G. Petridou, R. Raja, A.-K. Rieger, J. Rüpke, B. Sippel, E. Rubens Urciuoli, and L. Weiss. 2018. "Religion in the Making: The Lived Ancient Religion Approach." Religion 48(4): 568-593.

Albrile, Ezio. 2015. "Espiazioni ermetiche: Un excursus sulla metempsicosi." Studi e materiali di storia delle religioni (SMSR) 81(2): 597-615.

Alkier, Stefan, and Hartmut Leppin. 2018. "Juden, Christen, Heiden? Ein terminologischer Epilog." In Stefan Alkier and Hartmut Leppin (eds.),Juden, Christen, Heiden? Religiöse Inklusion und Exklusion in Kleinasien bis Decius, (Wissenschaftliche Untersuchungen zum Neuen Testament 400), Tübingen: Mohr Siebeck, 433-445.

Alroth, Brita, and Charlotte Scheffer (eds.). 20og. Attitudes towards the Past in Antiquity: Creating Identities. Proceedings of an International Conference Held at Stockholm University, 15-17 May 2009. Stockholm Studies in Classical Archaeology 14.

Anonymous. 1722. Einleitung zu des Heil. Röm. Reichs Kirchen-Staat, oder unpartheyische Nachricht, Wie Die drey im Heil. Römischen Reiche übliche Religionen, als die Römisch-Catholische, Evangelisch-Lutherische und Reformirte erwachsen, und was sie lehren; Theil 1:Der Zustand der Religionen, unter dem Heydenthum und Christenthum so wol vor als nach der Reformation Lutheri kürtzlich gewiesen wird. Franckfurth: Martini.

Anonymous. 1750. Die Götter Des Heydenthum In einem kurtzen Begriff vorgestellet. Zum Nutzen Der im Xaverianischen Convict Patrum Societatis Jesu Zu Cölln studierenden Edlen Jugend. [S.l.].

Arcari, Luca. 2017. "Beyond Conflicts: Cultural and Religious Cohabitations in Alexandria and Egypt between the 1st and the 6th Cent. CE." In Luca Arcari (ed.), Beyond Conflicts: Cultural and Religious Cohabitations in Alexandria and Egypt between the 1st and the 6th Century CE, (Studien und Texte zu Antike und Christentum 103), Tübingen: Mohr Siebeck, $1-24$.

Bailey, Lisa Kaaren. 2016. The Religious Worlds of the Laity in Late Antique Gaul. London: Bloomsbury.

Belayche, Nicole. 2007. "Religion et consommation de la viande dans le monde romain: des réalités voilées." Food and History 5 (1): 29-43.

Belayche, Nicole. 2018. "Les discours chrétiens sur la 'fin des cultes' publics au Levant: l'argument des sanctuaires." Revue de l'histoire des religions 235 (2): 209-232. 
Bergier, Nicolas Sylvestre. 1767. L'Origine Des Dieux Du Paganisme; Et Le Sens Des Fables Découvert Par Une Explication Suivie Des Poësies D'Hésiode. Paris: Humblot.

Beugnot, Arthur Auguste. 1835. Histoire de la destruction du paganisme en Occident. Paris: Didot.

Beyer, Peter. 2013. "Questioning the Secular/Religious Divide in a PostWestphalian World." International Sociology 28(6): 663-679.

Blömer, Michael, and Benedikt Eckhardt (eds.). 2018. Transformationen paganer Religion in der Kaiserzeit: Rahmenbedingungen und Konzepte. (Religionsgeschichtliche Versuche und Vorarbeiten 72). Berlin: de Gruyter.

Boin, Douglas. 2014. "Hellenistic 'Judaism' and the Social Origins of the Christian-Pagan Debate." Journal of Early Christian Studies 22(2): 167-196.

Boin, Douglas. 2015. "Late Antique Divi and Imperial Priests of the Late Fourth and Early Fifth Centuries." In Michele Salzman, R. Lizzi Testa, and M. Sághy (eds.), Pagans and Christians in Late Antique Rome: Conflict, Competition and Coexistence in the Fourth Century. New York: Cambridge University Press, 139-161.

Boissier, Gaston. 1891. La fin du paganisme: Étude sur les dernières luttes religieuses en occident au quatrième siècle. Paris: Hachette.

Bowring, Richard John. 2008. The Religious Traditions of Japan, 500-1600. Cambridge: Cambridge Univ. Press.

Boyarin, Daniel. 2004. "The Christian Invention of Judaism: The Theodosian Empire and the Rabbinic Refusal of Religion." Representations 85: 21-57.

Boyarin, Daniel. 2008. "The Christian Invention of Judaism: The Theodosian Empire and the Rabbinic Refusal of Religion." In Hent de Vries (ed.), Religion: Beyond a Concept. New York: Fordham University Press, 150-177.

Bremmer, Jan N. 2017a. "Paganism in the Hagiography of Asia Minor." In Walter Ameling (ed.), Die Christianisierung Kleinasiens in der Spätantike, (Asia Minor Studien 87), Bonn: Dr. Rudolf Habelt GmbH, 33-48.

Bremmer, Jan N. 2017b. "Pilgrimage Progress?" In Troels M. Kristensen and Wiebke Friese (eds.), Excavating Pilgrimage: Archaeological Approaches to Sacred Travel and Movement in the Ancient World, (Routledge Studies in Pilgrimage, Religious Travel and Tourism), London: Routledge, $275^{-284}$.

Bremmer, Jan N. 2018. "Transformations and Decline of Sacrifice in Imperial Rome and Late Antiquity." In Michael Blömer and Benedikt Eckhardt (eds.), Transformationen paganer Religion in der Kaiserzeit. Konzepte - Organisationsformen - Rechtliche Grundlagen, (Religionsgeschichtliche Versuche und Vorarbeiten 72), Berlin: de Gruyter, 215-256.

Brown, Peter Robert Lamont, and Rita Lizzi Testa (eds.). 2011. Pagans and Christians in the Roman Empire: The Breaking of a Dialogue (4th-6th century A.D.). (Christianity and History 9). Münster: LIT. 
Burchardt, Marian, and Monika Wohlrab-Sahr. 2013. "Multiple Secularities: Religion and Modernity in the Global Age' - Introduction." International Sociology 28(6): $605^{-611 .}$

Burigny, Jean Levesque de. 1754. Théologie payenne. Ou Sentimens des Philosophes \& des Peuples Payens les plus célebres, sur Dieu, sur l'Ame \& sur les Devoirs de l'Homme. Paris, De Bure.

Burrus, Virginia, Richard Lee Kalmin, Joel Marcus, and Hayim Lapim. 20o6. "Boyarin's Work: A Critical Assessment." Henoch 28: 7-30.

Cameron, Alan. 2011. The Last Pagans of Rome. Oxford: Oxford University Press.

Campany, Robert Ford. 2017. "Buddhism Enters China' in Early Medieval China." In Mu-chou Poo, H. A. Drake, and Lisa Raphals (eds.), Old Society, New Belief: Religious Transformation of China and Rome, ca. 1st-6th Centuries, New York: Oxford University Press, $13-34$.

Cecconi, Giovanni Alberto. 2007. "Come finisce un rituale pagano: La caterva di Cesarea di Mauritania." In Elio Lo Cascio and Giovanna D. Merola (eds.), Forme di aggregazione nel mondo romano, Bari: Edipuglia, 345-361.

Choat, Malcolm, and Iain Gardner. 2013. A Coptic Handbook of Ritual Power (P. Macq. I 1). (The Macquarie papyri 1). Turnhout: Brepols.

Chuvin, Pierre. 1990. A Chronicle of the Last Pagans. (Revealing Antiquity Series 4). Cambridge, MA: Harvard University Press.

Cohn, Naftali S. 2013. The Memory of the Temple and the Making of the Rabbis. (Divinations: Rereading Late Ancient Religion). Philadelphia: University of Pennsylvania Press.

Cumont, Franz Valery Marie, and Corinne Bonnet. (1929) 2006. Les religions orientales dans le paganisme romain. (Bibliotheca Cumontiana: Scripta maiora 1). Torino: Aragno.

Curran, John R. 2000. Pagan City and Christian Capital: Rome in the Fourth Century. (Oxford Classical Monographs). Oxford: Clarendon Press.

Dasen, Véronique, and Ulrich Schädler (eds.). 2013. Jeux et jouets gréco-romains = Archeothema 37. Fontaine-lès-Dijon: Archeodunum.

Denzey Lewis, Nicola. 2017. "Popular Christianity and Lived Religion in Late Antique Rome: Seeing Magic in the Catacombs." In Lucy Grig (ed.), Popular Culture in the Ancient World, Cambridge: Cambridge University Press, 257-276.

DuLignon, A. 1753. Histoire De L'Idolatrie Payenne, Ou Description Poetique, Historique, Et Critique De Toutes Les Fausses Divinitez Du Paganisme. Amsterdam: Jean Joubert.

Dunning, Benjamin H. 2009. Aliens and Sojourners: Self as Other in Early Christianity. (Divinations: Rereading Late Ancient Religion). Philadelphia: University of Pennsylvania Press.

Ebeling, Florian. 2007. The Secret History of Hermes Trismegistus: Hermeticism from Ancient to Modern Times. Ithaca, NY: Cornell University Press. 
Elsner, Jas, and Ian Rutherford (eds.). 2005. Pilgrimage in Graeco-Roman \& Early Christian Antiquity: Seeing the Gods. Oxford: Oxford University Press.

Ferri, Giorgio. 2016. "L'ultima danza dei Salii: L'élite pagana di Roma e gli imperatori cristiani nel IV secolo." In Daniela Bonanno, Peter Funke, and Matthias Haake (eds.), Rechtliche Verfahren und religiöse Sanktionierung in der grichisch-römischen Antike: Akten einer deutsch-italienischen Tagung Palermo, 11.-13. Dezember 2014/ Procedimenti giuridici e sanzione religiosa nel mondo greco e romana: Atti di un convegno italo-tedesco Palermo, 11-13 dicembre 2014, Stuttgart: Steiner, 281-293.

Fischer, Helena. 2013. Anthropologische Reflexionen in Dämonologien der hohen römischen Kaiserzeit:Justin - Apuleius - Censorinus (150-238 nach Christus). Erfurt: Thüringer Digitale Bibliothek.

Flower, Harriet I. 2010. Roman Republics. Princeton, NJ: Princeton University Press.

Frankfurter, David. 2008. "Iconoclasm and Christianization in Late Antique Egypt: Christian Treatments of Space and Image." In Johannes Hahn, Stephen Emmel, and Ulrich Gotter (eds.), From Temple to Church: Destruction and Renewal of Local Cultic Topography in Late Antiquity, (Religions in Graeco-Roman World 163), Leiden: Brill, 135-159.

Friedheim, Emmanuel. 2006. Rabbinisme et Paganisme en Palestine romaine: Étude historique des Realia talmudiques (Ir-IVème siècles). (Religions in the Graeco-Roman World 157). Leiden: Brill.

Gasparini, Valentino, Maik Patzelt, Rubina Raja, Anna-Katharina Rieger, Jörg Rüpke, and Emiliano Rubens Urciuoli (eds.). 2020. Lived Religion in the Ancient Mediterranean World: Approaching Religious Transformations from Archaeology, History and Classics. Berlin: de Gruyter.

Gibbon, Edward. 1776. The History of the Decline and Fall of the Roman Empire. London: W. Strahan and T. Cadell.

Goddard, Christophe J. 2006. "The Evolution of Pagan Sanctuaries in Late Antique Italy (Fourth-Sixth Centuries A.D.): A New Administrative and Legal Framework." In Massimiliano Ghilardi, Christophe J. Goddard, and Pierfrancesco Porena (eds.), Les Cités de L'Italie Tardo-Antique (IV-VI Siècle) - Institutions, Économie, Société, Culture et Religion, (Collection de l'École Française de Rome 369), Rome: École française de Rome, 19-308.

Gordon, Richard. 2011. "Archaeologies of Magical Gems." In Chris Entwistle and Noel Adams (eds.), "Gems of Heaven": Recent Research on Engraved Gemstones in Late Antiquity c. AD 200-600, (British Museum Research Publication 177), London: British Museum Press, 39-49.

Haas, Christopher. 1997. Alexandria in Late Antiquity: Topography and Social Conflict. Baltimore: The Johns Hopkins University Press.

Hahn, Johannes. 2008. From Temple to Church: Destruction and Renewal of Local Cultic Topography in Late Antiquity. Leiden: Brill. 
Handley, Mark A. 2017. "Scratching as Devotion: Graffiti, Pilgrimage and Liturgy in the late Antique and Early Medieval West." In Katharina Bolle, Carlos Machado, and Christian Witschel (eds.), The Epigraphic Cultures of Late Antiquity, (HABEs 6o), Stuttgart: Steiner, $555^{-593}$.

Heinzelmann, Martin. 1976. Bischofsherrschaft in Gallien: Zur Kontinuität römischer Führungsschichten vom 4. bis zum 7. Jahrhundert. Soziale, prosopographische und bildungsgeschichtliche Aspekte. Beihefte der Francia 5. Munich: Artemis.

Holleman, A. J. 1976. Pope Gelasius I and the Lupercalia. Amsterdam: Hakkert.

Hunter-Crawley, Heather. 2012. "Pilgrimage made Portable: A Sensory Archaeology of the Monza-Bobbio Ampullae." HE ROM 1: 135-156.

Isele, Bernd. 2010. Kampf um Kirchen: Religiöse Gewalt - heiliger Raum und christliche Topographie in Alexandria und Konstantinopel (4. Jh.). (Jahrbuch für Antike und Christentum - Ergänzungsband Kleine Reihe 4). Münster: Aschendorff Verlag.

Johannes, and Friedrich Wilhelm Hagen. 1796. Sieg des Christenthums über Juden- und Heidenthum oder die Offenbarung Johannis. Erlangen: Palm.

Kajanto, Iiro. 1981. "Pontifex Maximus as the Title of the Pope." Arctos 15: 37-52.

Kollmar-Paulenz, Karénina. 2018. "History Writing and the Making of Monoglian Buddhism." Archiv für Religionsgeschichte 20: 135-156.

Koschorke, Albrecht. 2012. Wahrheit und Erfindung: Grundzüge einer Allgemeinen Erzähltheorie. Frankfurt am Main: S. Fischer.

Kratz, Reinhard G. 2018. "Moses: Creating a Founding Figure." Archiv für Religionsgeschichte 20(1): 61-75.

Kristensen, Troels Myrup. 2012. "Miraculous Bodies: Christian Viewers and the Transformation of 'Pagan' Sculpture in Late Antiquity." In Stine Birk and Birte Poulsen (eds.), Patrons and Viewers in Late Antiquity, Aarhus: Aarhus University Press, 31-66.

Krumenacker, Yves. 2015. "The Use of History by French Protestants and its Impact on Protestant Historiography." In Bernd-Christian Otto, Susanne Rau, and Jörg Rüpke (eds.), History and Religion: Narrating a Religious Past, (Religionsgeschichtliche Versuche und Vorarbeiten 68), Berlin: de Gruyter, 189-201.

Lake, Kirsopp (ed.). 1926. Eusebius, Ecclesiastical History. (Loeb Classical Library). Cambridge, MA: Harvard University Press.

Lannoy, Annelies. 2012. Het christelijke mysterie: De relatie tussen het vroege christendom en de heidense mysterieculten in het denken van Alfred Loisy en Franz Cumont, in de context van de modernistische crisis. Ghent: Universiteit Gent, Faculteit Letteren $\&$ Wijsbegeerte.

Lannoy, Annelies. 2020. Alfred Loisy and the Making of History of Religions: A Study of the Development of Comparative Religion in the Early 2oth Century. (Religionsgeschichtliche Versuche und Vorarbeiten 74). Berlin: de Gruyter.

Lannoy, Annelies, and Corinne Bonnet. 2018. "Narrating the Past and the Future: The Position of the religions orientales and the mystères païens in the 
Evolutionary Histories of Religion of Franz Cumont and Alfred Loisy." Archiv für Religionsgeschichte 2O(1): 157-182.

Leemans, Johan (ed.). 2010. Martyrdom and Persecution in Late Antique Christianity: Festschrift Boudewijn Dehandschutter. (Bibliotheca ephemeridum theologicarum Lovaniensium 241). Leuven: Peeters.

Leone, Anna. 2013. The End of the Pagan City: Religion, Economy, and Urbanism in Late Antique North Africa. Oxford: Oxford University Press.

Lightfoot, Jane L. 2007. The Sibylline Oracles: With Introduction, Translation, and Commentary on the First and Second Books. Oxford: Oxford University Press.

Luginbühl, Thierry. 2015. "Ritual Activities, Processions and Pilgrimages." In Rubina Raja and Jörg Rüpke (eds.), A Companion to the Archaeology of Religion in the Ancient World, Malden: Wiley, 41-59.

Maas, Michael. 1992. John Lydus and the Roman Past: Antiquarianism and Politics in the Age of Justinian. London: Routledge.

Machado, Carlos. 2009. "Religion as Antiquarianism: Pagan Dedications in Late Antique Rome." In John Bodel and Mika Kajava (eds.), Dediche sacre nelmondo grecoromano: Diffusione, funzioni, tipologie/Religious Dedications in the Greco-Roman World: Distribution, Typology, Use. (Acta Instituti Romani Finlandiae 35), Roma: Institutum Romanum Finlandiae, 331-354.

Maier, Harry O. 2016. "Early Christian Martyrology, Imperial Thirdspace and Mimicry: Taking the Spatial Turn to the Arena." In Susanne Rau, Holt Meyer, and Katharina Waldner (eds.), Space Time of the Imperial, (Spatio Temporality/RaumZeitlichkeit 1). Berlin: de Gruyter, 353-384.

Meinzer, Michael. 1992. Der französische Revolutionskalender (1792-1805): Planung, Durchführung und Scheitern einer politischen Zeitrechnung. (Ancien Régime, Aufklärung und Revolution 20). Munich: Oldenbourg.

Miller, Peter N. 2001. "Taking Paganism Seriously: Anthropology and Antiquarianism in Early Seventeenth-Century Histories of Religion.” Archiv für Religionsgeschichte 3: 183-209.

Momigliano, Arnaldo. 1992. "From the Pagan to the Christian Sibyl: Prophecy as History of Religion." In Arnaldo Momigliano, Nono contributo alla storia degli studi classici e del mondo antico, Rome: Storia e letteratura, 725-744.

Moormann, Eric M. 2011. Divine Interiors: Mural Paintings in Greek and Roman Sanctuaries. (Amsterdam Archaeological Studies 16). Amsterdam: Amsterdam University Press.

Morgan, David. 2015. "Religion and Embodiment in the Study of Material Culture." In John Barton (ed.), Oxford Research Encyclopedia of Religion. Oxford: Oxford University Press. doi:10.1093/acrefore/9780199340378.013.32.

Mulsow, Martin. 2014. "Opfer, Tempel, Münzen und der Transfer von Bildern: Zur Rolle der numismatischen Illustration im religionsgeschichtlichen Antiquarianismus.” In 
Sabine Frommel and Eckhard Leuschner (eds.), Architektur- und Ornamentgraphik der Frühen Neuzeit: Migrationsprozesse in Europa: ICOPE-Tagung, Gotha 27.29.10.2011, (Hautes Études: Histoire de l'art), Rome: Campisano Editore, 295-312.

Nagel, Alexander K., Bernd U. Schipper, and Ansgar Weymann (eds.). 20o8. Apokalypse: Zur Soziologie und Geschichte religiöser Krisenrhetorik. Frankfurt: Campus-Verlag.

Noethlichs, Karl Leo. 1971. "Die gesetzgeberischen Maßnahmen der christlichen Kaiser des 4. Jh. gegen Häretiker, Heiden und Juden.” Ph.D. diss., Cologne.

Noethlichs, Karl Leo. 1986. "Heidenverfolgung." Reallexikon für Antike und Christentum 13: 1149-9o.

Noethlichs, Karl Leo. 2015. "The Legal Framework of Religious Identity in the Roman Empire." In Éric Rebillard and Jörg Rüpke (eds.), Group Identity and Religious Individuality in Late Antiquity. (CUA Studies in Early Christianity). Washington, DC: Catholic University of America Press, 13-27.

Ormerod, Oliver. 16o6. The picture of a papist: or, A relation of the damnable heresies, detestable qualities, and diabolicall practises of sundry hereticks in former ages, and of the papists in this age. Where in is plainly shewed, that there is scarse any heresie which the auncient Church knew, and withal condemned to the pit of hell, which the Romish Church hath not raked vp againe, and propounded to the world with new varnish and fresh colours. Together with a discourse of the late treason, and of the late execution of some of the traitors... Written to stop the mouthes of those, that complaine of rigour, and scandalize the state of cruelty, in their iust seueritie. Whereunto is annexed a certain treatise, intituled Pagano-pagismus: wherein is prooued by irrefragable demonstrations, that papisme is flat paganisme: and that the papists doe resemble the very pagans, in aboue seuenscore seuerall things. At London, Printed [by R. Bradock] for Nathaniel Fosbrooke, and are to be sold at his shop, at the west end of Paules: [8], 83, 9o-137, 168-203, 264-275, [1]; 56, 47-62 p.

Otto, Bernd-Christian, Susanne Rau, and Jörg Rüpke (eds.). 2015. History and Religion: Narrating a Religious Past. (Religionsgeschichtliche Versuche und Vorarbeiten 68). Berlin: de Gruyter.

Petts, David. 2011. Pagan and Christian: Religious Change in Early Medieval Europe. (Debates in Archaeology). London: Bristol Classical Press.

Praet, Danny. 2014. "Oriental Religions and the Conversion of the Roman Empire: The Views of Ernest Renan and of Franz Cumont on the Transition from Traditional Paganism to Christianity." In David Engels and Peter van Nuffelen (eds.), Religion and Competition in Antiquity, (Collection Latomus 343), Brussels: Peeters, 285-307.

Reader, Ian. 2006. "Japanese New Religious Movements." In Mark Juergensmeyer (ed.), The Oxford Handbook of Global Religion. Oxford: Oxford University Press. doi: 10.1093/oxfordhb/9780195137989.003.0015.

Rives, James. 2011. "Religious Choice and Religious Change in Classical and Late Antiquity: Models and Questions." ARYS 9: 265-280. 
Robinson, Chase F. 2015. "History and Heilsgeschichte in Early Islam: Some Observations on Prophetic History and Biography." In Bernd-Christian Otto, Susanne Rau, and Jörg Rüpke (eds.), History and Religion: Narrating a Religious Past. (Religionsgeschichtliche Versuche und Vorarbeiten 68), Berlin: de Gruyter, 119-150.

Ronning, Christian. 2007. "Pontifex Maximus, charismatischer Herrscher, , allen gemeinsamer Bischof' oder ,dreizehnter Apostel'? Das römische Herrschaftsverständnis und der christliche Kaiser." In Florian Schuller and Hartmut Wolff (eds.), Konstantin der Große: Kaiser einer Epochenwende, Lindenberg: Josef Fink, 125-149.

Rordorf, Willy. 1972. Sabbat und Sonntag in der alten Kirche. (Traditio Christiana 2). Zürich: Theologischer Verlag.

Rouwhorst, Gerard. 2017. "Sacrifice in Early Christianity: The Social Dimensions of a Metaphor." In Joachim Duyndam, Anne-Marie Korte, and Marcel Poorthuis (eds.), Sacrifice in Modernity: Community, Ritual, Identity: From Nationalism and Nonviolence to Health Care and Harry Potter, (Studies in Theology and Religion 22). Leiden: Brill, 132-146.

Rüpke, Jörg. 2005. "Bilderwelten und Religionswechsel." In Raban von Haehling (ed.) Griechische Mythologie und frühes Christentum, Darmstadt: Wissenschaftliche Buchgesellschaft, 359-376.

Rüpke, Jörg. 2008. Fasti sacerdotum: A Prosopography of Pagan, Jewish, and Christian Religious Officials in the City of Rome, 300 BC to AD 499. Oxford: Oxford University Press.

Rüpke, Jörg. 2011a. "History." In Michael Stausberg and Steven Engler (eds.), The Routledge Handbook of Research Methods in the Study of Religion, London: Routledge, 285-309.

Rüpke, Jörg. 2011b. "Individual Appropriation and Institutional Changes: Roman Priesthoods in the Later Empire." In Giovanni A. Cecconi and Chantal Gabrielli (eds.), Politiche religiose nel mondo antico e tardo antico: poteri e indirizzi, forme del controllo, idee e prassi di tolleranza - atti del Convegno internazionale di studi (Firenze, 24-26 settembre 2009), Bari: edipuglia, 261-273.

Rüpke, Jörg. 2012. “Lived Ancient Religion: Questioning 'Cults' and 'Polis Religion.” Mythos 5: 191-204.

Rüpke, Jörg. 2015a. “Construing 'Religion' by Doing Historiography: The Historicisation of Religion in the Roman Republic." In Bernd-Christian Otto, Susanne Rau, and Jörg Rüpke(eds.),HistoryandReligion:Narrating aReligiousPast,(Religionsgeschichtliche Versuche und Vorarbeiten 68), Berlin: de Gruyter, 45-62.

Rüpke, Jörg. 2015b. "Religious Agency, Identity, and Communication: Reflecting on History and Theory of Religion." Religion 45(3): 344-366.

Rüpke, Jörg. 2016a. "Creating Groups and Individuals in Textual Practices." Religion in the Roman Empire 2(1): 3-9. 
Rüpke, Jörg. 2016b. Religious Deviance in the Roman World: Superstition or Individuality. Cambridge: Cambridge University Press.

Rüpke, Jörg (ed.). 2018a. "Creating Religion(s) by Historiography." Special issue, Archiv für Religionsgeschichte 20(1).

Rüpke, Jörg. 2018b. "Living Urban Religion: Blind Spots in Boundary Work." Historia Religionum 10: 53-64.

Rüpke, Jörg. 2018c. Pantheon: A New History of Roman Religion. Princeton, NJ: Princeton University Press.

Rüpke, Jörg. 2018d. "Religious Agency, Sacralisation, and Tradition in the Ancient City." Istrazivanya 29(1): 22-38.

Rüpke, Jörg. 2019. "Lived Ancient Religion.” In John Barton (ed.), Oxford Research Encyclopedia of Religion, Oxford: Oxford University Press. Doi 10.1093/acrefore/ 9780199340378.013.633.

Rüpke, Jörg. 2020. Urban Religion: A Historical Approach to Urban Growth and Religious Change. Berlin: de Gruyter.

Rüsen, Jörn. 1996. "Some Theoretical Approaches to Intercultural Comparative Historiography." History and Theory 35(4): $5^{-22}$.

Sainte-Croix, Guillaume-Emmanuel-Joseph Guilhem de Clermont-Lodève, and Karl Gotthold Lenz. 179o. Des Freyherrnvon Sainte-Croix Versuch über die alten Mysterien. Gotha: Ettinger.

Sauer, Eberhard. 2002. The Archaeology of Religious Hatred in the Roman and Early Medieval World. Stroud: Tempus.

Seeber, Otto. 1991. "Kriegstheologie und Kriegspredigten in der Evangelischen Kirche Deutschlands im Ersten und Zweiten Weltkrieg." In Marcel van der and Gottfried Mergner (eds.), Kriegsbegeisterung und mentale Kriegsvorbereitung: Interdisziplinäre Studien, Berlin: Duncker \& Humblot, 233-258.

Shaw, Brent D. 2011. Sacred Violence: African Christians and Sectarian Hatred in the Age of Augustine. Cambridge: Cambridge University Press.

Shorrock, Robert. 2011. The Myth of Paganism: Nonnus, Dionysus and the World of Late Antiquity. (Classical Literature and Society). London: Bristol Classical Press.

Smith, Jonathan Z. 2001. "A Twice-Told Tale: The History of the History of Religion's History." Numen 48(2): 131-146.

Stausberg, Michael. 2001. "Kohärenz und Kontinuität - Überlegungen zur Repräsentation und Reproduktion von Religionen." In Michael Stausberg (ed.), Kontinuitäten und Brüche in der Religionsgeschichte: Festschrift für Anders Hultgård zu seinem 65. Geburtstag am 23.12.2001, (Ergänzungsbände zum Reallexikon der germanischen Altertumskunde 31), Berlin: de Gruyter, 596-619.

Stausberg, Michael. 2009. "Renaissancen: Vermittlungsformen des Paganen." In Hans G. Kippenberg, Jörg Rüpke, and Kocku von Stuckrad (eds.), Europäische 
Religionsgeschichte: Ein mehrfacher Pluralismus, Göttingen: Vandenhoeck \& Ruprecht, 1, 695-722.

Stemberger, Günter. 2018. "Creating Religious Identity: Rabbinic Interpretations of the Exodus.” Archiv für Religionsgeschichte 20(1): 45-59.

Stroumsa, Guy G. 2013. "False Prophets of Early Christianity." In Beate Dignas, Robert Parker, and Guy G. Stroumsa (eds.), Priests and Prophets Among Pagans, Jews and Christians, (Studies in the History and Anthropology of Religion 5). Leuven: Peeters, 208-229.

Teitler, Hans C. 2016. The Last Pagan Emperor: Julian the Apostate and the War Against Christianity. New York: Oxford University Press.

Testa, Rita Lizzi (ed.). 2013. The Strange Death of Pagan Rome: Reflection on a Historiographical Controversy. Turnhout: Brepols.

Tzischirner, Heinrich Gottlob. 1829. Der Fall des Heidenthums 1. Leipzig: Nieder.

Ullucci, Daniel C. 2012. The Christian Rejection of Animal Sacrifice. Oxford: Oxford University Press.

Van Henten, J. W., and B. A. G. M. Dehandschutter. 1989. Die Entstehung der jüdischen Martyrologie. (Studia Post Biblica 38). Leiden: Brill.

Vinzent, Markus. 2019. Offener Anfang: Die Entstehung des Christentums im 2. Jahrhundert. Freiburg im Breisgau: Herder.

Waldner, Katharina. 2008. Für die Wahrheit sterben: Antike Martyriumserzählungen zwischen Religion, Politik und Philosophie. Erfurt: Habilitationsschrift.

Watts, Edward J. 2010. Riot in Alexandria: Tradition and Group Dynamics in Late Antique Pagan and Christian Communities. (The Transformation of the Classical Heritage 46). Berkeley: University of California Press.

Watts, Edward Jay. 2015. The Final Pagan Generation. (Transformation of the Classical Heritage 53). Oakland: University of California Press.

Woolf, Greg. 2017. "Archaeological Narratives of the Collapse Complex Societies." In Takaski Minamikawa (ed.), Decline and Decline-Narratives in the Greek and Roman World: Proceedings of a Conference held in Oxford in March 2017, Kyoto: Kyoto University, 113-123.

York, Michael. 2003. Pagan Theology: Paganism as a World Religion. New York: New York University Press.

Zander, Helmut. 1999. Geschichte der Seelenwanderung in Europa: Alternative religiöse Traditionenvon der Antike bis heute. Darmstadt:Wissenschaftliche Buchgesellschaft. 